\title{
Sınıf Öğretmeni Adaylarının Bilgisayar ve İnternet Kullanımı Özyeterlilik Algıları ile Çevrimiçi Öğrenmeye Hazırbulunuşluluk Düzeyleri Arasındaki İlişkinin İncelenmesi
}

\author{
Mehmet Akif Bircan ${ }^{1 *}$, Engin Zabun² \\ ${ }^{1}$ Sivas Cumhuriyet Üniversitesi Eğitim Fakültesi Temel Eğitim Bölümü, Sivas, Türkiye \\ ${ }^{2}$ Sivas Cumhuriyet Üniversitesi Eğitim Fakültesi Türkçe ve Sosyal Bilimler Eğitimi Bölümü, Sivas, Türkiye \\ ORCID: M.A. Bircan (0000-0003-2442-0600), E. Zabun (0000-0001-8132-8953)
}

\begin{abstract}
Özet: Bu çalışmada sınıf öğretmeni adaylarının bilgisayar ve internet kullanımı özyeterlilik algıları ile çevrimiçi öğrenmeye hazırbulunuşluluk düzeyleri incelenmiştir. Araştırma ilişkisel tarama modelinde desenlemiştir. Araştırmanın çalışma grubunu 3 devlet üniversitesinin eğitim fakültesi bünyesinde öğrenim gören 209 sınıf öğretmeni adayı oluşturmaktadır. Veri toplama aracı olarak, kişisel bilgi formu, "Sınıf Öğretmenleri İçin Bilgisayar ve İnternet Kullanımı Öz yeterlilik Algısı Ölçeği” ve "Çevrimiçi Öğrenme Hazırbulunuşluluk Ölçeği” kullanılmıştır. Verilerin analizinde betimsel istatistikler, t-testi ve ANOVA testinden faydalanılmıştır. Araştırma sonucunda sınıf öğretmeni adaylarının bilgisayar ve internet kullanımı özyeterlilik algılarının kısmen yapabilirim düzeyinde olduğu belirlenmiştir. Buna ek olarak sınıf öğretmeni adaylarının kendilerine ait bilgisayarları olup olmaması durumuna göre bilgisayar ve internet kullanımı özyeterlilik ortalama puanları arasında anlamlı farklılık olduğu; evlerinde internet bağlantısı olup olmaması durumuna göre ise bilgisayar ve internet kullanımı özyeterlilik ortalama puanları arasında anlamlı farklılık olmadığı sonucuna ulaşılmıştır. Ayrıca araştırmada sınıf öğretmeni adaylarının çevrimiçi öğrenme hazırbulunuşluluk düzeylerinin orta düzeyin üzerinde olduğu belirlenmiştir. Çalışmaya katılan sınıf öğretmeni adaylarının çevrimiçi öğrenme hazırbulunuşluluk düzeylerinin kendilerine ait bilgisayarları olup olmaması durumuna göre anlamlı farklılık gösterdiği; evlerinde internet bağlantısı olup olmaması durumuna göre ise anlamlı farklııı göstermediği sonucuna ulaşımıştır. Bunlarla birlikte sınıf öğretmeni adaylarının bilgisayar ve internet kullanımı özyeterlilik algıları ile çevrimiçi öğrenme hazırbulunuşluluk düzeyleri arasında güçlü pozitif yönde bir ilişki olduğu bulunmuştur.
\end{abstract}

Anahtar kelimeler: öğretmen adayları, çevrimiçi öğrenme, özyeterlilik, hazırbulunuşluluk

\section{Investigation of the Relationship Between the Self-Efficacy Perceptions of Computer and Internet Use of Classroom Teacher Candidates and the Level of Online Learning Readiness}

\begin{abstract}
In this study, prospective classroom teachers were examined in terms of their perceptions about computer and internet use self-efficacy, and their readiness levels for online learning. The study was designed according to the correlational survey model. The study group consisted of 209 prospective classroom teachers, who were enrolled at the faculties of education in 3 state universities. Personal Information Form, "Computer and Internet Use Self-Efficacy Scale for Elementary School Teachers" and "Online Learning Readiness Scale" were used as data collection tools. The data were analyzed using descriptive statistics, $t$-test and ANOVA. As a result of the study, computer and internet use self-efficacy perceptions of prospective classroom teachers were determined to be at the level of partial compatibility. In addition, there was a significant difference between the mean computer and internet use self-efficacy scores of prospective classroom teachers according to the state of having or not having computers of their own. It was also concluded that there was no significant difference between computer and internet use self-efficacy scores according to the availability of internet connection at home. Moreover, it was determined in the study that the online learning readiness level of prospective classroom teachers was above the moderate level. Online learning readiness levels of the participating prospective classroom teachers differed significantly according to the state of having or not having computers of their own. It was also concluded that there was no significant difference according to the availability of internet connection at home. Furthermore, a strong positive correlation was found between computer and internet use self-efficacy perceptions and online learning readiness levels of prospective classroom teachers.
\end{abstract}

Keywords: prospective teachers, online learning, self-efficacy, readiness

*Yazışma Adresi / Address for Correspondence: M.A. Bircan, Email: bircanmehmetakif@gmail.com

Geliş Tarihi / Received Date: 05.04.2021

Kabul Tarihi / Accepted Date: 04.05.2021

Doi: 10.32329/uad.899769

\section{Giriș}

Covid-19 salgını, çok kısa sürede yayılarak dünyayı etkisi altına almış ve insanoğlunun günlük yaşam şeklini çok önemli şekilde değiştirmiştir. Salgının doğrudan ve en derin etkilerinin görüldüğü alanlardan birisi de eğitim olmuș dünyanın her yerinde uygulanan yüz yüze eğitim yerini uzaktan eğitime bırakmıștır. 
Ülkemizde Milli Eğitim Bakanlığı'nın 12 Mart 2020'de aldığı kararla bütün okullarda eğitime iki hafta ara verilmiş daha sonrası için de eğitimin uzaktan eğitim ile devam edeceği yönünde karar alınmıştır [Milli Eğitim Bakanlığı (MEB), 2020]. Yükseköğretim Kurumu ise üniversitelere gönderdiği yazı ile 23 Mart 2020 tarihinden itibaren uzaktan eğitim imkânı ve alt yapısı bulunanların uzaktan eğitim modeli ile eğitim öğretime devam etmesi gerektiğini duyurmuştur [Yükseköğretim Kurumu (YÖK), 2020]. İlgili kararlar sonrası ülkemizde bütün eğitim kademelerinde uzaktan eğitim modeli uygulanmaya başlanmıştır.

Uzaktan eğitim 19.yüzyılın ikinci yarısından itibaren gazete ve mektupla, öğrenmeyi zaman ve mekândan bağımsız hale getirmiş, farklılaşan öğrenme ihtiyaçlarını karşılamak için gerekli araçları sağlamıştır. Günümüzde ise daha çok internete dayalı olarak gerçekleştirilmektedir (İşman, 2011). Bugün dünya nüfusunun \%64,7'sinin internet kullanıcısı olması (Internet World Stats, 2020) bu durumu kolaylaştırmaktadır. Ayrıca ülkelerin bilgi ve iletişim teknolojisi cihazlarına sahip olma imkânı olmayan bireylere yönelik geliştirdiği politika ve projeler de uzaktan eğitim modelinin uygulanmasını yaygınlaştırmaktadır. Örneğin MEB 2021 yılında internet ve cihaz ihtiyacı olan öğrenciler için 500.000 tablet dağıtımı gerçekleştirmiştir (MEB, 2021).

Salgın sonrası uzaktan eğitim modelinin zorunluluk haline gelmesi ile birlikte çevrimiçi öğretim yükseköğretim kurumlarında yaygın bir öğretim aracı olarak kullanılmaya başlanmıştır (Sarıtaş ve Barutçu, 2020). Çevrimiçi öğrenme “öğrencilerin geleneksel öğrenme-öğretme etkinliklerinden farklı ortamda, aynı anda birçok öğrenme kaynağına ulaşarak ve çoğu durumda sınıf ortamında olduklarından daha fazla etkileşim içine girerek öğrenmeyi kaynaklardan uzakta gerçekleştirdikleri bir öğrenme sürecidir" (Çalışkan, 2002). Çevrimiçinin öğrenmenin öğrenenlere sağladığı bazı avantaj ve faydalar vardır. Çevrimiçi öğrenmenin sağladığı en önemli avantaj interneti temel alması yönüyle internetin sağladığı bütün avantajları sunmasıdır. Çevrimiçi öğrenmede internet temel iletişim ve öğrenme kaynağını oluşturduğundan bu tür öğrenmede öğrenciler bilgi kaynaklarını kolaylıkla belirleyebilmekte ve kaynaklara kolaylıkla ulaşıp kullanabilmektedirler (Horton, 2000). Çevrimiçi öğrenmenin öğrencilere hem sosyal, hem akademik, hem de işbirliği becerileri geliştirme, içeriğe kolaylıkla istedikleri zaman istedikleri yerden ulaşma olanağı tanıma, bireysel hızlarına uygun öğrenme ve konular hakkında istedikleri kadar alıştırma ve tekrar yapma olanağı sunması gibi başka avantajları bulunmaktadır (Horzum ve diğerleri, 2017). Çevrimiçi öğrenmenin sağladığı avantajların yanında bazı problemler de bulunmaktadır. Verduin ve Clark (1994) ve Lynch (2002) çevrimiçi öğrenmede yaşanan temel problemleri eğitimi bırakma, yalnızlık, öğrenme stili uyumu, zaman yönetimi sağlayamama, öğrencilerin yeni ortamdaki bilgiyi genelleme becerilerini geliştirememe, erişimde eşitsizlik, ihtiyaçlara uygun olmama ve yüz yüze eğitimle benzer şekilde ders vermeye çalışma şeklinde özetlemişlerdir. Çevrimiçi öğrenmenin yukarıda sıralanan avantajlarından faydalanabilmek için öğrenenlerin çevrimiçi öğrenme hazırbulunuşluluğuna sahip olması gerekmektedir (Yurdugül ve Sırakaya, 2013; Sakal, 2017). Smith (2005) çevrimiçi öğrenme hazırbulunuşluluğunu "Çevrimiçi ortamda, öğrenmeye yönelik motivasyona, gerekli olan teknolojik becerileri öğrenme stiline ve kendi öğrenmesini yönetmesi için gerekli bilgi, beceri ve inançlara sahip olma durumu" olarak tanımlamaktadır Öğrenenlerin bu hazırbulunuşluluğa sahip olması çevrimiçi öğrenmenin başarılı bir şekilde yürütülmesini doğrudan etkilemektedir (Oliver, 2001; Hukle, 2009; Ibrahim, Silong ve Samah, 2012).

Günümüzde salgın ile birlikte uzaktan eğitim modelinin yaygınlaşması, çevrimiçi öğrenme ve e-öğrenmenin öneminin artması bir başka kavramın daha ön plana çıkmasına neden olmuştur. Bu da bilgisayar ve internet kullanımı konusundaki öğretmenlerin özyeterlilik algılarıdır. Çünkü bilgisayarların ve internetin eğitim- öğretim ortamlarında kullanılmasını zorunlu kılan bu süreçte hedeflenen başarıyı, bu teknoloji araçlarını kullanacak eğitimcilerin bilişim teknolojilerine karşı tutum, kaygı ve özyeterlik algıları şekillendirmektedir. Bandura'nın sosyal öğrenme teorisi çalışmalarında bireyin kendi bilgi, tutum ve becerileri yani yetkinlikleriyle ilgili algısı olarak ortaya çıkan öz yeterlilik (Bandura, 1986), bireyin bir işe başlaması, devam ettirmesi ve tamamlaması süreçlerinde başarılı olmasına "bir işi yapma gücünü sağlayan özel bilgi, görevini yerine getirme gücü” şeklinde tanımlanmaktadır (Türk Dil Kurumu, 2005). Özyeterlik algısı bireylerin zor zamanlarda nasıl davranmaları gerektiğini belirler ve bireyin davranışlarında açıkça gözlenebilir (Yaman, Koray ve Altunçekiç, 2004). Özyeterlik algısı yüksek olan bireyler, bir olayı gerçekleştirme veya bir görevi tamamlamak için başkaları tarafından güdülenmeye gerek duymadan, kendi kendine motivasyonu içsel olarak yapabilir (Kapıc1, 2003).

Çevrimiçi öğrenmenin başarıya ulaşabilmesi için eğitmenlerin ve öğrenenlerin hazırbulunuşluluklarının tespit edilmesi gerekmektedir. Alan yazın incelendiğinde öğrenenlerin çevrimiçi öğrenme hazırbulunuşluluklarını belirlemeye çalışan araştırmaların olduğu görülmektedir (Özgür, Çuhadar ve Akgün, 2014; Alsancak-Sırakaya ve Yurdugül, 2016; Sakal, 2017; Bülbül ve Yordam, 2018; Sarıtaş ve Barutçu, 2020). Smith (2005) öğrenenlerin çevrimiçi öğretime hazır olmasını bilgisayar, mobil telefon ve interneti kullanabilmesi ile ilişkili olduğunu ifade etmektedir. Sırakaya ve Yurdugül (2013) de çevrimiçi öğrenme sürecinin etkiliği açısından öğrenenlerin bilgisayar ve interneti kullanabilme özyeterliliğinin önemli olduğu söylemektedir. Bu nedenle bilgisayar ve internet teknolojilerini etkin kullanabilme becerisini gerektiren çevrimiçi öğrenme sürecinde öğrenenlerin söz konusu yeterliliklerinin tespit edilmesi de önem arz et- 
mektedir. Alan yazın incelendiğinde öğretmen adaylarının bilgisayar ve internet kullanımı özyeterliliği ile ilgili araştırmalara rastlanılmamıştır. Ayrıca bilgisayar ve internet kullanımı özyeterlilik algıları ile çevrimiçi öğrenmeye hazırbulunuşluluk düzeyleri ile ilgili bir çalışma ile karşılaşılmamıștır. Bu nedenle araştırmanın alana katkı sağlayacağı ifade edilebilir.

\subsection{Problem cümlesi}

$\mathrm{Bu}$ araştırmada sınıf öğretmeni adaylarının çevrimiçi öğrenme hazırbulunuşluluğu ile bilgisayar ve internet kullanımı özyeterlilik algı düzeyleri belirlenerek ve bu iki değişken arasındaki ilişki ortaya çıkarılmaya çalışılmıştır. Bu doğrultuda araştırmada aşağıda verilen problem cümlelerine yanıt aranmıştır.

1. Sınıf öğretmeni adaylarının bilgisayar ve internet kullanımı özyeterlilik algıları

a) Nasildır?

b) Kendilerine ait bilgisayarları olup olmaması durumuna göre anlamlı farklılık göstermekte midir?

c) Evlerinde internet bağlantısı olup olmaması durumuna göre anlamlı farklılık göstermekte midir?

2.Sınıf öğretmeni adaylarının çevrimiçi öğrenme hazırbulunuşluluk düzeyleri

a) Nasildır?

b) Kendilerine ait bilgisayarları olup olmaması durumuna göre anlamlı farklılık göstermekte midir?

c) Evlerinde internet bağlantısı olup olmaması durumuna göre anlamlı farklılık göstermekte midir?

3. Sınıf öğretmeni adaylarının bilgisayar ve internet kullanımı özyeterlilik algıları ile çevrimiçi öğrenme hazırbulunuşluluk düzeyleri arasında anlamlı bir ilişki var mıdır?

\section{YÖNTEM}

\subsection{Araştırmanın deseni}

$\mathrm{Bu}$ araştırmada sınıf öğretmeni adaylarının bilgisayar ve internet kullanımı özyeterlilik algıları ile çevrimiçi öğrenmeye hazırbulunuşluluk düzeyleri arasındaki ilişki belirlenmeye çalışıldığından ilişkisel tarama modeli kullanılmıștır. Bu araștırmalarda, bir grubun belirli özelliklerini belirleyebilmek için veri toplanır ve iki ya da daha fazla değișken arasındaki ilişki belirlenmeye çalışılır (Büyüköztürk ve diğerleri, 2011).

\section{2. Çalışma Grubu}

Araştırmanın çalışma grubunu üç farklı devlet üniversitesinin eğitim fakültelerinde öğrenim gören 209 sınıf öğretmeni adayı oluşturmaktadır. Araștırma grubunda yer alan öğretmen adaylarının cinsiyetlerine ve sınıflarına ait betimsel istatistikler Tablo 1'de sunulmuştur.
Tablo 1. Sınıf Öğretmeni Adaylarının Cinsiyet Değişkenine Göre Betimsel İstatistikleri

\begin{tabular}{|c|c|c|c|}
\hline & Gruplar & $f$ & $\%$ \\
\hline \multirow{3}{*}{ Cinsiyet } & Kadın & 167 & 79,9 \\
\cline { 2 - 4 } & Erkek & 42 & 20,1 \\
\hline \multirow{3}{*}{ Sinıf } & 1. sınıf & 26 & 12,4 \\
\cline { 2 - 4 } & $2 . \sin$ If & 60 & 28,7 \\
\cline { 2 - 4 } & 3. sınıf & 63 & 30,1 \\
\cline { 2 - 4 } & $4 . \sin$ If & 60 & 28,7 \\
\hline & Toplam & 209 & 100 \\
\hline
\end{tabular}

Tablo 1 incelendiğinde araştırmaya katılan sınıf öğretmeni adaylarının 167'sinin (\% 79,9) kadın, 42'sinin (\% 20,1) erkek olduğu; araştırmaya katılan sınıf öğretmeni adaylarının 26'sının (\% 12,4) 1. sinıfa, 60'inın (\% 28,7) 2. sınıfa, 63'ünün (\% 30,1) 3.sınıfa ve 60'ının (\% 28,7) 4. sınıfa devam ettiği görülmektedir.

\subsection{Veri toplama araçları}

Kişisel bilgi formu: Araştırmaya katılan sınıf öğretmeni adaylarının kişisel bilgilerini tespit edebilmek amacıyla araştırmacılar tarafından hazırlanmıştır.

Sınıf öğretmenleri için bilgisayar ve internet kullanımı özyeterlilik algısı ölçeği (SÖBİKÖAÖ): Şad ve Demir (2015) tarafından sınıf öğretmenlerinin bilgisayar ve internet kullanımı özyeterlilik algılarını belirleyebilmek için geliştirilmiştir. Bilgisayar kullanımı özyeterliliği ve internet kullanımı özyeterliliği olmak üzere iki faktör ve onaltı maddeden oluşmaktadır. Ölçek maddelerinin içtutarlılık yönünden güvenirliğine ilişkin Cronbach Alfa ve Guttman iki yarı güvenilirlik katsayıları bilgisayar kullanımı özyeterlilik algısı için 0, 943 ve 0,928 olarak ve internet kullanımı özyeterlilik algısı için 0,933 ve 0,928 olarak bulunmuştur.

Çevrimiçi öğrenme hazırbulunuşluluk ölçeği (ÇÖHÖ): Yurdugül ve Sırakaya (2013) tarafından yetişkinlerin çevrimiçi öğrenme hazırbulunuşluluk düzeylerini belirleyebilmek için geliştirilmiştir. Bilgisayar/internet özyeterliliği, özgüdümlü öğrenme, öğrenci kontrolü, öğrenme için motivasyon ve çevrimiçi öğrenme özyeterliliği olmak üzere beș faktör ve onsekiz maddeden oluşmaktadır. Ölçek maddelerinin Cronbach Alpha güvenirlik katsayısı bilgisayar/internet özyeterliği için 0.92, özgüdümlü öğrenme için 0.84, öğrenen kontrolü için 0.85, öğrenme için motivasyon için 0.80 ve çevrimiçi iletişim özyeterliği için 0.91 'dir. Ölçeğin tamamı için ise hesaplanan Cronbacha Alpha güvenirlik katsayısı 0.87 'dir.

\subsection{Veri toplama süreci}

Araştırma verileri 2020-2021 eğitim öğretim yılı bahar döneminde Google form aracılığı toplanmıștır.

\subsection{Verilerin analizi}

Araştırma verileri SPSS 21 programı kullanılarak analiz edilmiştir. Araştırmada nicel verileri analiz edilirken ölçeklerden elde edilen puanların betimsel istatistiklerine 
bakılarak normallik durumlarına karar verilmiștir.

Tablo 2. Ölçeklere Ait Betimsel İstatistik Değerleri

\begin{tabular}{|c|c|c|}
\hline & Çarpıklık katsayısı & Basıklık Katsayısı \\
\hline SÖBíKÖAÖ & $-1,36$ & 1.45 \\
\hline ÇÖHÖ &,- 51 &, 85 \\
\hline
\end{tabular}

Tablo 2 incelendiğinde SÖBİKÖAÖ ve ÇÖHÖ'den elde edilen çarpıklık ve basıklık katsayısı değerlerinin $-2,+2$ aralığında olduğu görülmektedir Bu iki değerin -2 ve +2 değerleri arasında olduğu durumlarda dağılımın normal dağılım olarak gerçekleştiği kabul edilmektedir (George ve Mallery, 2010; Pekbay, 2017) Bu nedenle ölçeklerden elde edilen verilerin normal dağılım özelliği gösterdiği ifade edilebilir. Bu bilgilerin doğrultusunda araştırmada verilerin analiz edilmesinde bağımsız gruplar t-testi ve korelasyon testlerinden faydalanılmıștır.

Bilgisayar ve internet kullanımı özyeterlilik algıları ölçeğindeki seçenekler 0 Yapamayacağımdan kesinlikle eminim", "5 Kismen yapabilirim" ve "10 Yapabileceğimden kesinlikle eminim" șeklinde on eşit aralığa bölünmüştür. Sınıf öğretmeni adaylarının bu ölçekten elde ettikleri puanların yorumlanmasında bu puanlara karşıllk gelen ifadeler dikkate alınmıştır. Çevrimiçi öğrenmeye hazırbulunuşluluk ölçeği de 1 "Hiç katılmıyorum", 2 "Katılmıyorum", 3 "Kararsızım", 4 "Katılıyorum" ve 5 "Kesinlikle katılıyorum" şeklinde beş eşit aralığa bölünmüștür. Sınıf öğretmeni adaylarının bu ölçekten elde ettikleri puanların yorumlanmasında ise bu puanlara karşılık gelen ifadeler dikkate alınmıştır.

\section{BULGULAR}

Sınıf öğretmeni adaylarının bilgisayar ve internet kullanımı özyeterlilik algılarına ait betimsel istatistikler Tablo 4'te sunulmuştur.

Tablo 3. Sınıf Öğretmeni Adaylarının Bilgisayar ve Internet Kullanımı Özyeterlilik Algıları

\begin{tabular}{|c|c|c|c|c|}
\hline & & $N$ & $\bar{X}$ & Ss \\
\hline $\begin{array}{c}\text { Alt boyut- } \\
\text { lar }\end{array}$ & Bilgisayar kullanımı özyeterliliği (BKÖ) & 209 & 6,97 & 16,13 \\
\cline { 2 - 5 } & Internet kullanımı özyeterliliği (IKÖ) & 209 & 6,75 & 14,05 \\
\hline Toplam & & 209 & 6,86 & 28,74 \\
\hline
\end{tabular}

Tablo 3 incelendiğinde sınıf öğretmeni adaylarının bilgisayar kullanımı özyeterlilik algılarının $(\bar{x}=6,97)$, internet kullanımı özyeterlilik algılarının $(\overline{\mathrm{x}}=6,75)$ ve bilgisayar ve internet kullanımı özyeterlilik algılarının $(\bar{x}=6,75)$ kısmen yapabilirim düzeyinde olduğu görülmektedir.

Sınıf öğretmeni adaylarının kendilerine ait bilgisayarı olup olmama durumuna göre bilgisayar ve internet kullanımı özyeterlilik algılarının anlamlı farklılık gösterip göstermediğine bağımsız gruplar t-testi yapılarak bakılmış ve analiz sonuçları Tablo 4'te sunulmuştur.

Tablo 4 incelendiğinde sınıf öğretmeni adaylarının kendine ait bilgisayarı olup olmama değișkenine göre bil- gisayar ve internet kullanımı özyeterlilik ortalama puanları arasında anlamlı farklılık olduğu görülmektedir $([\mathrm{t}(207)=-3,18, \mathrm{p}<.05])$.

Tablo 4. Sınıf Öğretmeni Adaylarının Bilgisayar ve İnternet Kullanımı Özyeterlilik Algılarının Kendilerine Ait Bilgisayarı Olup Olma Değişkenine Göre Analizi

\begin{tabular}{|c|c|c|c|c|c|c|}
\hline & $\mathrm{N}$ & $\overline{\mathrm{X}}$ & Ss & sd & $\mathrm{t}$ & $\mathrm{P}$ \\
\hline 1.grup (Bilgisayarı var) & 101 & 7,26 & 23,40 & 207 & $-3,18$ &, 002 \\
\hline 2. grup (Bilgisayarı yok) & 108 & 6,48 & 31,90 & & & \\
\hline
\end{tabular}

Sınıf öğretmeni adaylarının evlerinde internet bağlantısı olup olmama durumuna göre bilgisayar ve internet kullanımı özyeterlilik algılarının anlamlı farklılık gösterip göstermediğine bağımsız gruplar t-testi yapılarak bakılmış ve analiz sonuçları Tablo 5'da sunulmuştur.

Tablo 5. Sınıf Öğretmeni Adaylarının Bilgisayar ve İnternet Kullanımı Özyeterlilik Algılarının Evlerinde İnternet Bağlantısı Olup OImama Değişkenine Göre Analizi

\begin{tabular}{|c|c|c|c|c|c|c|}
\hline & $\mathrm{N}$ & $\overline{\mathrm{X}}$ & $\mathrm{Ss}$ & $\mathrm{sd}$ & $\mathrm{t}$ & $\mathrm{P}$ \\
\hline 1.grup (İnternet bağlantısı var) & 165 & 7,01 & 26,40 & 56,63 & $-2,03$ &, 046 \\
\hline 2. grup (Internet bağlantısı yok) & 44 & 6,29 & 35,06 & & & \\
\hline
\end{tabular}

Tablo 5 incelendiğinde sınıf öğretmeni adaylarının evlerinde internet bağlantısı olup olmama değişkenine göre bilgisayar ve internet kullanımı özyeterlilik ortalama puanları arasında anlamlı farklılık olduğu görülmektedir $([\mathrm{t}(56,63)=-2,03, \mathrm{p}>.05])$.

Sınıf öğretmeni adaylarının çevrimiçi öğrenme hazırbulunuşluluk düzeylerine ait betimsel istatistikler Tablo 6'de sunulmuștur.

Tablo 6. Sınıf Öğretmeni Adaylarının Çevrimiçi Öğrenme Hazırbulunuşluluk Düzeyleri

\begin{tabular}{|c|c|c|c|}
\hline & N & $\bar{X}$ & Ss \\
\hline ÇÖHD & 209 & 3.75 & 10,24 \\
\hline
\end{tabular}

Tablo 6 incelendiğinde sınıf öğretmeni adaylarının çevrimiçi öğrenmeye hazırbulunuşluluk düzeylerinin $(\bar{x}=3$, 75) katıllyorum düzeyinde olduğu görülmektedir.

Sınıf öğretmeni adaylarının kendilerine ait bilgisayarı olup olmama durumuna göre çevrimiçi öğrenme hazırbulunuşluluk düzeylerinin anlamlı farklılık gösterip göstermediğine bağımsız gruplar t-testi yapılarak bakılmış ve analiz sonuçları Tablo 7' de sunulmuştur.

Tablo 7. Sınıf Öğretmeni Adaylarının Çevrimiçi Öğrenmeye Hazırbulunuşluluk Düzeylerinin Kendilerine Ait Bilgisayarı Olup Olma Değişkenine Göre Analizi

\begin{tabular}{|c|c|c|c|c|c|c|}
\hline & $\mathrm{N}$ & $\overline{\mathrm{X}}$ & $\mathrm{Ss}$ & $\mathrm{sd}$ & $\mathrm{t}$ & $\mathrm{p}$ \\
\hline 1.grup (Bilgisayarı var) & 101 & 3,83 & 9,75 & 207 & $-2,04$ &, 042 \\
\hline 2. grup (Bilgisayarı yok) & 108 & 3,67 & 10,53 & & & \\
\hline
\end{tabular}

Tablo 7 incelendiğinde sınıf öğretmeni adaylarının kendine ait bilgisayarı olup olmama değişkenine göre çevrimiçi öğrenmeye hazırbulunuşluluk düzeyi ortalama 
puanları arasında anlamlı farklılık olduğu görülmektedir $([\mathrm{t}(207)=-2,04, \mathrm{p}<.05])$.

Sınıf öğretmeni adaylarının evlerinde internet bağlantısı olup olmama durumuna göre çevrimiçi öğrenme hazırbulunuşluluk düzeylerinin anlamlı farklılık gösterip göstermediğine bağımsız gruplar t-testi yapılarak bakılmış ve analiz sonuçları Tablo 8'da sunulmuştur.

Tablo 8. Sınıf Öğretmeni Adaylarının Çevrimiçi Öğrenmeye Hazırbulunuşluluk Düzeylerinin Evlerinde İnternet Bağlantısı Olup Olmama Değişkenine Göre Analizi

\begin{tabular}{|c|c|c|c|c|c|c|}
\hline & $\mathrm{N}$ & $\overline{\mathrm{X}}$ & $\mathrm{Ss}$ & $\mathrm{sd}$ & $\mathrm{t}$ & $\mathrm{p}$ \\
\hline $\begin{array}{c}\text { 1.grup } \\
\text { (Internet bağlantısı var) }\end{array}$ & 165 & 3,76 & 12,53 & 207 &,- 427 &, 670 \\
\hline $\begin{array}{c}\text { 2. grup } \\
\text { (Internet bağlantısı yok) }\end{array}$ & 44 & 3,72 & 9,57 & & & \\
\hline
\end{tabular}

Tablo 8 incelendiğinde sınıf öğretmeni adaylarının evlerinde internet bağlantısı olup olmama değişkenine göre çevrimiçi öğrenmeye hazırbulunuşluluk düzeyi ortalama puanları arasında anlamlı farklılık olmadığı görülmekte$\operatorname{dir}([\mathrm{t}(207)=-, 427 \mathrm{p}>05])$.

Sınıf öğretmeni adaylarının bilgisayar ve internet kullanımı özyeterlilik algıları ile çevrimiçi öğrenme hazırbulunuşluluk düzeyleri arasında anlamlı bir iliş̧i bulunup bulunmadığı korelasyon testi ile analiz edilmiş ve analiz sonuçları Tablo 9'da sunulmuştur.

Tablo 9. Sınıf Öğretmeni Adaylarııın Bilgisayar ve İnternet Kullanımı Özyeterlilik Algıları ile Çevrimiçi Öğrenmeye Hazırbulunuşluluk Düzeyleri Arasındaki Illişki

\begin{tabular}{|c|c|c|l|l|}
\hline & & ÇÖHD & & \\
\hline BiKÖA & $r$ &, 651 & & \\
\hline & $p$ &, 000 & & \\
\hline
\end{tabular}

Tablo 9 incelendiğinde sınıf öğretmenlerinin bilgisayar ve internet kullanımı özyeterlilik algıları ile çevrimiçi öğrenmeye hazırbulunuşluluk düzeyleri arasında güçlü pozitif bir ilişki olduğu görülmektedir $(\mathrm{r}=, 651, \mathrm{p}<.05)$.

\section{SONUÇ VE TARTIŞMA}

$\mathrm{Bu}$ araştırmada sınıf öğretmeni adaylarının bilgisayar ve internet kullanımı özyeterlilik algıları, çevrimiçi öğrenme hazırbulunuşluluk düzeyleri ve bu iki değişken arasındaki ilişki incelenmiştir.

Araştırma sonucunda sınıf öğretmeni adaylarının bilgisayar kullanımı özyeterlilik algılarının orta düzeyde olduğu tespit edilmiştir. Bu araştırma sonucuna benzer başka araştırma sonuçları da vardır. Örneğin İpek ve Acuner (2011) tarafından sınıf öğretmeni adaylarının bilgisayar özyeterliliklerini belirlemek amacıyla yapılan araştırmada da sınıf öğretmeni adaylarının bilgisayar özyeterlilik düzeylerinin orta düzeyde olduğu sonucuna ulaşılmıştır. Ayrıca sınıf öğretmenlerinin bilgisayar özyeterliliklerini belirlemek amacıyla yapılan çalışmalarda da benzer sonuçlar elde edilmiştir. Bu ifadeyi destekler nitelikte Seferoğlu ve Seferoğlu ile Akbıyık (2005) ve Özçelik (2006) tarafından yapılan iki ayrı çalışmada da sınıf öğretmenlerinin bilgisayar özyeterlilik düzeylerinin orta düzeyde olduğu sonucuna ulaşılmıștır. Yine literatürde bu araştırma bulgularından farklı olarak sınıf öğretmenlerinin bilgisayar özyeterlilik algılarının yüksek olduğu araştırma sonuçları da vardır. Çeliköz, Bulut ve Çeliköz (2018) tarafından sınıf öğretmenlerinin bilgisayar ile ilgili özyeterlilik algılarını belirleyebilmek amacıyla yapılan araştırmada sınıf öğretmenlerinin bilgisayar ile ilgili özyeterlilik algılarının yüksek düzeyde olduğu sonucuna ulaşılmıştır.

Araştırma sonucunda sınıf öğretmeni adaylarının internet kullanımı özyeterlilik algılarının orta düzeyde olduğu sonucuna ulaşılmıştır. Alan yazın incelendiğinde sınıf öğretmeni adaylarının ve sınıf öğretmenlerinin internet kullanımı özyeterlilik algıları ile ilgili araştırmaların olmadığ araştırmaların daha çok eğitsel amaçlı internet kullanımına yönelik özyeterlilik inançları veya internet kullanımına yönelik tutum ile ilgili olduğu görülmektedir. Tuncer ve Özüt (2012) tarafından yapılan araştırmada sınıf öğretmeni adaylarının eğitsel amaçlı internet kullanımı özyeterlilik inançlarının orta düzeyde olduğu sonucuna ulaşılmıştır. Usta, Bozdoğan ve Yıldırım (2007) sınıf öğretmeni adaylarının internet kullanımına yönelik tutumlarını değerlendirdikleri araştırmada sınıf öğretmeni adaylarının internet kullanımına yönelik tutumlarının orta düzeyde olduğunu tespit etmişlerdir.

Araştırma sonucunda sınıf öğretmeni adaylarının kendine ait bilgisayarı olup olmama değişkenine göre bilgisayar ve internet kullanımı özyeterlilik ortalama puanları arasında anlamlı farklılık olduğu sonucuna ulaşılmıştır. Çetin ve Güngör (2014) yaptıkları araştırma sonucunda öğretmenlerin kişisel bilgisayara sahip olma durumlarının bilgisayar öz-yeterlik inançlarını olumlu yönde etkilediği sonucuna ulaşmışlardır. Bu bulgulardan hareketle öğretmen adaylarının kendi bilgisayarlarına sahip olma durumlarının bilgisayar kullanımı ve internet kullanımı özyeterliliklerini artırabileceği ifade edilebilir. Bunların yanı sıra araştırmada sınıf öğretmeni adaylarının evlerinde internet bağlantısı olup olmama değişkenine göre bilgisayar ve internet kullanımı özyeterlilik ortalama puanları arasında anlamlı farklılık olduğu sonucuna ulaşılmıştır. Öğretmen adaylarının internet ile vakit geçirme süreleri arttıkça internet kullanımı özyeterliliklerinin artması beklenen bir sonuçtur. Bu ifadeyi destekler nitelikte Topal ve Akgün (2014) yaptıkları araştırmada öğretmen adaylarının internet ile vakit geçirdikçe eğitim amaçlı internet kullanımı öz-yeterlilik algılarının arttığını tespit etmiştir.

Araştırma sonucunda sınıf öğretmeni adaylarının çevrimiçi öğrenmeye hazırbulunuşluluk düzeylerinin orta düzeyin üzerinde olduğu sonucuna ulaşılmıştır. Özgür, Çuhadar ve Akgün (2014) de yapmış oldukları çalışmada öğretmen adaylarının çevrimiçi öğrenmeye hazırbu- 
lunușluluk düzeylerinin orta düzeyin üzerinde olduğu sonucuna ulaşmışlardır. Yine bu bulgularla aynı doğrultuda Çakır ve Horzum (2015) da yaptığı araștırmada öğretmen adaylarının çevrimiçi öğrenmeye hazırbulunuşluluk düzeylerinin ortalamanın üzerinde olduğu sonucuna ulaşmışlardır. Araştırmada öğretmen adaylarının çevrimiçi öğrenmeye hazırbulunuşluluk düzeylerinin bilgisayar sahibi olup olmama durumuna göre anlamlı farklılık gösterdiği tespit edilmiştir. Bilgisayar sahibi olma durumu bireylerin teknoloji kullanımı yeterliliklerini olumlu olarak etkilemektedir. Bu bulgunun da sözkonusu etkinin bir sonucu olabileceği ifade edilebilir. Pullu ve Gömleksiz (2020) üniversite öğrencilerinin çevrimiçi öğrenmeye hazırbulunuşluluk düzeylerini inceledikleri araştırmada teknoloji kullanım yeterliliği yüksek olan öğrencilerin çevrimiçi öğrenme hazırbulunuşluluklarının yüksek olduğunu tespit etmişlerdir. Araştırmada öğretmen adaylarının çevrimiçi öğrenme hazırbulunuşluluk düzeylerinin evde internet bağlantısı olup olmama durumuna göre anlamlı farklılık göstermediği bulgusu elde edilmiştir. Yine Özgür, Çuhadar ve Akgün (2014) tarafından yapılan araştırmada da öğretmen adaylarının internet kullanım sıklığına göre çevrimiçi öğrenmeye hazırbulunuşluluk düzeyleri arasında interneti kullanma sıklı̆̆ duruma göre anlamlı bir farklılık oluşmadığı bulgusuna ulaşılmıştır. Bu bulgular ışığında öğretmen adaylarının internet ile geçirdikleri sürenin çevrimiçi öğrenme hazırbulunuşluluk düzeylerine bir etkisinin olmadığı ifade edilebilir.

Araştırmada bilgisayar ve internet kullanımı özyeterlilik algısı ile çevrimiçi öğrenmeye hazırbulunuşluluk arasında pozitif anlamlı bir ilişki olduğu sonucuna ulaşılmıştır. Çevrimiçi öğrenmeye hazırbulunuşluluğun bilgisayar ve internet kullanımı yeterliliği ile doğrudan ilişkisi vardır. Araştırmada elde edilen bu bulgu da bu ifadenin bir göstergesidir. Özgür, Çuhadar ve Akgün (2014) öğretmen adaylarının bilgisayar ve internet kullanımı konusundaki özgüvenlerinin çevrimiçi öğrenmeye hazırbulunuşluluk düzeylerini olumlu etkilediğini ifade etmiştir.

Sonuç olarak sınıf öğretmeni adaylarının bilgisayar ve ineternet kullanımı özyeterlilik algıları kısmen yapabilirim düzeyinde olduğu; çevrimiçi öğrenmeye hazırbulunuşluluk düzeylerinin ise orta düzeyinin üzerinde olduğu belirlenmiştir. Ayrıca öğretmen adaylarının bilgisayar ve internet kullanımı özyeterlilik algıları ile çevrimiçi öğrenmeye hazırbulunuşluluk düzeyleri arasında pozitif güçlü bir ilişki olduğu görülmüştür. Bu bulgulardan harekelte şu öneriler sunulabilir:

- Araştırmanın çalışma grubu üç farklı devlet üniversitesi ile sınırlıdır. Yapılacak araştırmalarda çalışma grubu genişletilebilir.

- Araştırma sınıf öğretmeni adaylarına yönelik gerçekleștirilmiştir. Eğitim fakültelerinde öğrenim gören diğer bölümlerden öğrenciler ile aynı amaca yönelik araştırmalar yürütülebilir.
- Araştırma sonucunda elde edilen öğretmen adaylarının bilgisayar ve internet kullanımı özyeterlilik algılarının yüksek olmadığı bulgusundan hareketle öğretmen adaylarının bilgisayar ve internet kullanımı yeterliliklerini artıracak içerikler geliştirilebilir.

- Araştırma sonucunda elde edilen öğretmen adaylarının çevrimiçi öğrenmeye hazırbulunuşluluk düzeylerinin yüksek olmadığı bulgusundan hareketle öğretmen adaylarının çevrimiçi öğrenmeye hazırbulunuşluluk düzeylerini artıracak içerikler geliştirilebilir.

\section{KAYNAKÇA}

Alsancak Sarıkaya, D. ve Yurdugül, H. (2016). Öğretmen adaylarının çevrimiçi öğrenme hazır bulunuşluluk düzeylerinin incelenmesi: Ahi Evran Üniversitesi örneği. Ahi Evran Üniversitesi Kırşehir Eğitim Fakültesi Dergisi, 17(1), 185-200.

Bandura, A. (1986). Social foundations of thought and action: A social cognitive theory-. Englewoods Cliffs, NJ: Prentice Hall.

Bülbül, T. ve Yordam, M . (2018). Öğretmenlerin özyeterlilik algılarının çevrimiçi öğrenmeye yönelik hazırbulunuşlulukları ile ilişkisi. Trakya Üniversitesi Sosyal Bilimler Dergisi, 20 (1) , 447-470. DOI: 10. 26468/trakyasobed.412098

Büyüköztürk, Ş., Çakmak, E.K., Akgün, K.Ş. ve Demirel, F. (2011). Bilimsel araştırma yöntemleri. (9. Baskı). Ankara: Pegem A Yayıncilık.

Çakır, Ö. ve Horzum, M.B. (2015). Öğretmen adaylarının çevrimiçi öğrenmeye hazırbulunuşluk düzeylerinin çeşitli değişkenler açısından incelenmesi. Eğitimde Kuram ve Uygulama, 11(1), 1-15.

Çalışkan, H. (2002). Çevrimiçi (Online) eğitimde öğrenci etkileşimi. Açık ve Uzaktan Eğitim Sempozyumu, Eskişehir.

Çeliköz, N., Bulut, S. ve Çeliköz, M . (2018). Sınıf öğretmenlerinin bilgisayarla ilgili öz yeterlilik algıları. MANAS Sosyal Araştırmalar Dergisi, 7(1), 15-24.

Çetin, O. ve Güngör, B . (2014). İlköğretim öğretmenlerinin bilgisayar öz-yeterlik inançları ve bilgisayar destekli öğretime yönelik tutumları. Ondokuz Mayıs Üniversitesi Eğitim Fakültesi Dergisi, 33(1), 5-77.

George, D., ve Mallery, M. (2010). SPSS for windows step by step: a simple guide ve reference, 17.0 update (10a ed.) Boston: Pearson.

Horton, W. (2000). Designing web based training. New York: John Wiley \& Sons.

Horzum, M. B., Demir Kaymak, Z. Ve Canan Güngören, Ö. (2017). Çevrimiçi öğrenmede öğrenci engelleri ölçeğinin türkçe'ye uyarlanması: geçerlik ve güvenirlik çalışması. Açıköğretim Uygulamaları ve Araştırmaları Dergisi, 3(2), 61-84.

Hukle, D.R. L. (2009). An evaluation of readiness factors for online education. (Yayımlanmamış Doktora Tezi). Mississippi State University. Mississippi.

Internet World Stats (2017). Internet users in the worlds. http:// www.internetworldstats.com/stats.htm adresinden 15 Ocak 2021tarihinde ulaşılmıştır.

İbrahim. D. Z.. Silong. A. D. ve Samah. B. A. (2002). Readiness 
and aminde touards online learning among virtual students. Paper Presented in 15th Annual Conference of the Asian Association of Open Universities. Nueva Delhi. India.

İpek, C. ve Acuner, H. Y. (2011). Sınıf öğretmeni adaylarının bilgisayar öz-yeterlik inançları ve eğitim teknolojilerine yönelik tutumları. Ahi Evran Üniversitesi Eğitim Fakültesi Dergisi, 2(2),23-40.

İşman, A. (2011). Uzaktan eğitim. Ankara: Pegem Akademi Yayıncilık.

Kapıcı, Z. U., (2003), İlköğretim öğretmenlerinin özyeterlik algıları ve sınıf-içi iletişim örüntüleri. (Yayımlanmamış Yüksek Lisans Tezi). Dokuz Eylül Üniversitesi Eğitim Bilimleri Enstitüsü: İzmir.

Lynch, M. M. (2002). The online educator: a guide to creating the virtual classroom. London: Routledge Falmer Taylor \& Francis Group.

MEB, (2020). Bakan Selçuk, koronavirüs'e karşı eğitim alanında alınan tedbirleri açıkladı. Erişim tarihi: 24.02.2021, https:// www.meb.gov.tr/bakan-selcuk-koronaviruse-karsi-egitim-alaninda-alinan-tedbirleri-acikladi/haber/20497/tr

MEB, (2021). 500.000 tablet bilgisayar dağıtımının ikinci fazındayız. Erişim tarihi. 27.02.2021, https://www.meb.gov. tr/500000-tablet-bilgisayar-dagitiminin-ikinci-fazindayiz/ haber/22182/tr

Pekbay, C. (2017). Fen teknoloji mühendislik ve matematik etkinliklerinin ortaokul ögrencileri üzerindeki etkileri (Yayınlanmış Yüksek Lisans Tezi). Hacettepe Üniversitesi Eğitim Bilimleri Enstitüsü, Ankara

Oliver, R. G. (2001). Assuring the quality of online learning in australian higher education. Proceedings of 2000 Moving Online Conference. (pp. 222-231). Gold Coast, QLD. Norsearch Reprographics

Özgür, H., Çuhadar, C. ve Akgün, F. (2014). Öğretmen adaylarının çevrimiçi öğrenmeye yönelik hazırbulunuşluk düzeylerinin incelenmesi. 2nd International Instructional Technologies \& Teacher Education Symposium

Özçelik, H. (2006). İlköğretimde çalışan öğretmenlerin bilgisayar özyeterlikleri: Balıkesir ili örneği. (Yayınlanmamış yüksek lisans tezi). Anadolu Üniversitesi, Eğitim Bilimleri Enstitüsü, Eskişehir

Pullu, E. ve Gömleksiz, M. (2020). Meslekyüksekokulu öğrencilerinin covid 19 pandemi sürecinde çevrimiçi öğrenmeye ilişkin hazır bulunuşluk ve tutum düzeyleri arasındaki ilişkinin çeşitli değişkenler açısından incelenmesi . Milli Eğitim Dergisi, Salgın Sürecinde Türkiye'de ve Dünyada eğitim , 757-782 . dol: 10.37669/milliegitim.788019

Sakal, M. (2017). Çevrimiçi öğrenmede öğrencilerin hazırbulunuşluk düzeylerinin demografik özelliklerine göre incelenmesi. Sosyal ve Beşeri Bilimler Araştırmaları Dergisi, 18 (39) , 81-102.

Sarıtaş, E. ve Barutçu, S. (2020). Öğretimde dijital dönüşüm ve öğrencilerin çevrimiçi öğrenmeye hazır bulunuşluğu: Pandemi döneminde Pamukkale Üniversitesi öğrencileri üzerinde bir araştırma. Journal of Internet Applications and Management, 11 (1) , 5-22. DOI: 10.34231/iuyd.706397

Seferoğlu, S. S. ve Akbıyık, C. (2005). Illköğretim öğretmenlerinin bilgisayara yönelik öz-yeterlik algıları üzerine bir çalışma. Eğitim Araştırmaları Dergisi, 19, 89-101.
Smith, P. (2005). Learning preferences and readiness for online learning. Educational Psychology, 25(1), 3-12.

Şad, S.N. ve Demir, O. (2015). Sınıf öğretmeleri için bilgisayar ve internet kullanımı özyeterlik algısı ölçeği: geçerlik ve güvenirlik çalışması. İlköğretim Online, 14(2), 489- 510.

Türk Dil Kurumu (2005). Türkçe sözlük. Ankara: Türk Dil Kurumu Yayınları.

Topal, M. ve Akgün, Ö. (2015). Eğitim fakültesinde okuyan öğretmen adaylarının eğitim amaçlı internet kullanımı öz-yeterlik algılarının incelenmesi: Sakarya Üniversitesi Örneği. Kastamonu Eğitim Dergisi, 23(1), 343-364.

Tuncer, M. ve Özüt, A. (2012). Sınıf öğretmeni adaylarının eğitsel Internet kullanımına yönelik özyeterlik inançları. Turkish Studies - International Periodical for the Languages, Literature and History of Turkish or Turkic, 7(2), 1079-1091.

Usta, E., Bozdoğan, A.E. ve Yıldırım, K. (2007). Sınıf öğretmeni adaylarının internet kullanımına ilişkin tutumlarının değerlendirilmesi. Ahi Evran Üniversitesi Kırşehir Eğitim Fakültesi Dergisi, 8(1), 209- 222.

Verduin, J. R. ve Clark, T. A. (1994). Uzaktan Eğitim: Etkin Uygulama Esasları (çev. İ. Maviş). Eskişehir: Anadolu Üniversitesi Basımevi.

Yaman, S., Koray, O. ve Altunçekic, A. (2004). Fen bilgisi öğretmen adaylarının özyeterlik inanç düzeylerinin incelenmesi üzerine bir araştırma. Türk Eğitim Bilimleri Dergisi, 2 (3), 355-366.

YÖK. (2020). Basın Açıklaması. Erişim tarihi: 27.02.2021, https://www.yok.gov.tr/Sayfalar/Haberler/2020/universitelerde-uygulanacak-uzaktan-egitime-iliskin-aciklama.aspx

Yurdugül, H. ve Sırakaya D. (2013). Çevrimiçi öğrenme hazırbulunuşluluk ölçeği: geçerlik ve güvenirlik çalışması. Eğitim ve Bilim Dergisi, 38(169), 391-406. 